\title{
Impact of education on purchase behaviour of luxury brands
}

\author{
Dr. R. Srinivasan, Dr. R. K. Srivastava and Prof.Sandeep Bhanot
}

\begin{abstract}
:
Purpose and objectives of the study:In this study, we aim to understand the influence of education on the frequency of buying luxury products, influence to buy luxury products and intention to purchase the same brand that they have previously purchased. Also we study the different luxury value dimensions and how these are influenced by education.

Research Methodology:Data was collected from 1200 respondents in Mumbai. These people belonged to people of both genders, different occupations, income groups, religions, age groups, education and marital status.

Results:It is found that there is a relation between education and the place from which they buy luxury brands. There is a significant difference in perception of financial value among people of different educational levels. There is a significant difference in perception of self-identity value among people of different educational levels.

Managerial implications:Luxury brand companies can target the right target segment by understanding how education influences the purchase of luxury brands and whether there is any significant difference in financial value, functional value, individual value and social value with respect to education.
\end{abstract}

Keywords: Education, luxury, purchase behaviour, luxury brands

\section{Introduction:}

1.1 Purchase behaviour: The actions a person takes in purchasing and using products and services, including the mental and social processes that precede and follow these actions can be called as purchase behaviour. It helps us to answer questions such as:

(i) Why people choose one product or brand over another?

(ii) How they make these choices, and

(iii) How companies use this knowledge to provide value to consumers

Purchase decision process: Behind the visible act of making a purchase, lies a decision that must be investigated. The purchase decision process is the stages a buyer passes through in making choices about which products and services to buy. There are five stages of purchase behaviour: (i) problem recognition (ii) information search (iii) alternative evaluation (iv) purchase decision (v) post purchase behaviour

1.2 Luxury brands: Luxury is no longer restricted today to only the rich and the selected few but is being used for mass marketing now. The concept of luxury has been changing dramatically across time and culture. Earlier, luxury was connected with things like wines, champagne, designer clothes and sports cars. These days, people have become richer and luxury is a blurred genre that is no longer the preserve of the elite. More and more consumers have increased their financial status as the old values of tradition and nobility have become less important. People are having much more disposable income in comparison to earlier generations, resulting in a tendency towards fulfilling personal needs and aspirations through experience. Therefore, it could be said that luxury is more about experience (Yeoman and McMahon-Beattie, 2010), rather than financial value. This is not to say that luxury is about status, but luxury is more than financial value. Indeed, they run hand in hand. The need for personal gratification and aspirations has led to greater emphasis on having things which make life better and easy. It means that consumers want to improve their life. This is what Danziger (2005) and Israel (2003) mean when they say that luxury is not just restricted to trophies and status symbols but also covers things giving aesthetic experience and indulgence. This is also due to increasing purchasing power of women in society, which is a good sign for luxury markets such as wellbeing, clothes and tourism. We see that the earlier concept of luxury of consumption and elitism stills prevails especially in emerging economies of China. In the recent times, the Global Financial Crisis has led consumers to re-examine their priorities and as a consequence, attitudes and behaviours towards luxury have changed.

In management field it is accepted to distinguish luxury products from necessary and ordinary products within their category by their basic characteristics. These include things like financial value, quality, aesthetics, exclusivity and status giving. All of these characteristics are relative terms. A luxury product is characterised by a relatively high rating on each of these dimensions compared to other products of its category (Trommsdorff and Heine 2008, p. 1670). Luxury brands are those whose ratio of functional utility to price is low while the ratio of intangible and situational utility to price is high. 
1.3 Influence of education on purchase of luxury brands: Education is one of the important demographic variables which can have an influence on purchase behaviour of luxury brands. Undergraduates, graduates and postgraduates can respond differently to the various attributes of luxury brands. They may want to purchase them from different places or look for different dimensions of luxury value. The perception of different luxury values like functional value, financial value, individual value and social value can be different for people of different educational levels.

\section{Statement of the problem/Need for the study:}

In this study, we want to understand the influence of education on different aspects of purchase behaviour of luxury brands like frequency of buying luxury products, influence to buy luxury products and intention to purchase the same brand that they have previously purchased. Also we study the different luxury value dimensions like financial value, functional value, individual value and social value and how these are influenced by education. Among the various demographic variables, we have selected education because perception of different dimensions of luxury value can vary for graduate, undergraduate and postgraduate consumers and luxury brand companies can use different strategies to cater to the requirements of these segments.

\section{Literature Review:}

3.1 Luxury brands: The concept of luxury is complex and subjective and its meaning is dependent on various personal and interpersonal motives (Vigneron\& Johnson 2004). In order to understand the meaning of luxury, we can first describe the nature of luxury, luxury goods, luxury brands and brand equity for luxury brands.

Kapferer (1997, p.253; as cited in Vigneron and Johnson 2004) summarised luxury as defining beauty, enlightening and providing good taste. According to him, luxury products provide sensory pleasure and is the appendage of the ruling or elite classes.

Webster (2002) defines it simply as "non-essential items". Cornell (2002) says that luxury can be characterised by a strong element of human involvement, scarcity or limited supply and value recognition by others. Similarly, Kapferer (1997) says that luxury exhibits beauty and aesthetics and can be applied to functional items. He also says that luxury has an enlightening effect and provides sensory pleasure. Berry (1994), similarly, characterizes luxury goods as items that rise desire and provide pleasure to its consumers.

Also the concept of rarity and exclusivity has not been forgotten, being highlighted by Pantzalis (1995). On the other hand, McKinsey (1990 in Wiedmann, Hennings, and Siebels 2009) sates that luxury goods are the ones that have the higher ratio of price-quality. Phau and Prendergast (2000) argue that luxury goods are those which exhibit exclusivity, brand image and identity, brand awareness and excellent in the minds of the consumers. Finally, Kapferer and Bastien (2008) argue that "luxury is qualitative and not quantitative" and is when "hedonism takes over functionality" as it has to be "multi-sensory and experiential" to each consumer. Thus, both authors claim that luxury is only a true luxury when some part of it is handmade and the brand has the capacity to provide exclusive services to their consumers.

Luxury is either a service or a good that is able to fill both functional and psychological needs of the consumer (Nia and Zaichkowsky 2000). Hence, the service and/or good has to be able to transmit to the customer extra pleasure (Kapferer 1997) and a truly multi-sensorial experience (Kapferer and Bastien 2008), as consumers are increasingly seeking more personal fulfilment and aspiration through experience (Yeoman, McMahon-Beatie and Brown 2005 \& Yeoman and Mc-Mahon-Beattie 2006). Luxury goods should present a high level of perceived quality (Phau and Prendergast 2000), as a high price (McKinsey 1990) and also a limited supply (Cornell 2002, p.47) to ensure the exclusivity and rarity required by customers (Pantzalis 1995; Phau and Prendergast 2000). Finally, we believe that luxury goods have to have some part of it handmade and that the brand has to be able to answer to customer's wishes and needs with special and customized offers (Kapferer and Bastien 2008).

According to Phau and Prendergast (2000), luxury represents much more nowadays; one of the most significant changes is that it is on necessarily expensive, but by no means is it a necessity (Brannen, 1996). Within the literature on luxury, McKinsey (1990) and Nueno\&Quelch (1998) defined luxury by the use of price and quality ratio. Whatever falls into the highest price and quality ratio category is regarded as luxury. This definition is in line with that of Berry's (1994) who has put forward that luxury is an expenditure that goes beyond what is necessary and he asserts that luxuries are not required( Berry, 1994, p.23).

Luxury products help to satisfy a consumer's functional needs and also fulfil him/her psychologically (Dubois, Czellar\& Laurent, 2001). A particular good can be desired as a luxury only if the ownership of the goods is able to provide pleasure (Berry, 1994). In addition, luxuries are by definition always out of the reach of mass consumption (Berry, 1994) and exclusivity and rarity are therefore features connected to the concept of luxury (Pantzalis, 1995). 


\subsection{Influence of education on purchase of luxury brands:}

Bernard Dubois \& Gilles Laurent (1993) explain that some differences among the various European countries can be observed and results indicate that income, education and occupation differentiate consumers to a far greater extent than country affiliation. It is observed that there is a positive effect of education upon luxury purchase. It would however appear that in the three Latin countries, France, Spain and Italy, the effect is strictly linear while there is a very limited additional impact of university education in the Anglo-Saxon world (U.K. and Germany). One possible explanation for this interesting result is cultural. While buying luxury brands is well accepted by the cultural elite in the Latin world, it would be much less so in puritan cultures. The number of brands known by university educated people compared with the middle-education group does not increase significantly in Anglo-Saxon countries while it does so in France, Spain and Italy.

A study by AlirezaMiremadi et al. (2011) aims to explore the possible effects of need for uniqueness's dimensions on fashion luxury brands purchase intentions and to compare Kish and Dubai market in this perspective. The definition of uniqueness for both markets is the same due to order of importance for each constructs in mind of participants in the survey while this definition remain the same between genders and among respondents with different level of education.

Ching-Yaw Chen et al. (2012) in their study explain that explore the differences in Taiwanese women's purchasing decisions towards two different categories: luxury goods and general products. Demographic variables like age, education, occupation, marital status, income play key factor in purchasing decisions. Taiwanese woman aged 21-40 dominate luxury goods shopping most of them being well educated and independent. They consider product origin, functionality, prices, reputation, brand awareness, appearance and design rather than TV shopping, venting bad mood, endorsers influence or just for the sake of it.

Sonny Nwankwo, Nicolas Hamelin, Meryem Khaled (2014) explain that more educated people, generally, indicated a greater tendency towards rational than impulse buying decisions.

\subsection{Dimensionalising Luxury:}

Wiedmann, K.P., N. Hennigs\& A. Siebels (2009) developed a luxury value model useful for studying the relationship between value perception and luxury consumption. Their model includes four luxury value dimensions: financial value, functional value, individual value and social value. Different authors have addressed different combinations of these luxury value dimensions. (a) Several authors have studied the financial value people derive from buying products they believe others cannot afford. Stokburger-Sauer \&Teichmann (2013) say that despite the fact that the functional value of luxury brands is usually not substantially higher than other non-luxury brands, luxury brands can reach substantial price premiums in the market over non-luxury ones.(b) Luxury consumption has also been studied from the perspective of the functional value luxury goods provide. Simply stated, some people buy luxury goods because they believe they offer superior quality \&perform better, that they are more user friendly, or more unique than their non-luxurybrand competitors are. Luxury brands are supposed to offer greater product quality \&performance than nonluxury brands (according to O'Cass\& Frost, 2002; \&Vigneron\& Johnson, 2004). Others have shown that perceived usability value drives purchases of luxury goods. Coulter, Price \&Feick (2003) have focused on the functional dimension of luxury brands. Gardyn (2002); Chadha \& Husband(2007) and Berthon et al. (2009) have studied about high reputation of luxury goods which illustrate functional, symbolic \&/or experiential values in perception of owners. Atwal \& Williams (2009) have said that luxury products no longer provide solely on functional values, but also, on emotional values and social values. Ko et. al. (2010) has emphasised on high quality value for luxury brands.

(c) Several researchers have studied the social value of luxury consumption. Vigneron\& Johnson, 2004; Wiedmannet al., (2009); Han,Y.J , J.C.Nunes\&X. Dreze, (2011), have studied the social orientation of luxury brands. Such social value has two sub-dimensions: snob value and prestige value. People seeking snob value derive value from buying scarce luxury goods that others cannot access. Prestige seeking consumers seek to conform to aspirational groups that consume such luxury goods to demonstrate that they belong to this group. (d) Individual value: Lipovetsky\& Roux (2003); Danziger, (2005); Geerts\&Veg-Sala (2011); Srinivasan, Srivastava, \&Bhanot(2013) have studied the personal oriented consumption of individuals and called it as emotional luxury. Social value can be associated with Self-identity, materialistic and hedonism values.

\section{Gap analysis:}

The study by Seringhaus, F. H. Rolf (2005) considers the impact of culture on purchase of luxury brands but other demographic variables like education have not been considered.

Yeomann\&Mc-Mahon-Beattie (2006) have said that modern societies seek more personal fulfilment and aspiration through experience, but they have not concentrated on aspects like limited supply and high price. Chaudhuri\&Majumdar (2006) have found that consumers are motivated to purchase luxury products to enhance self-concept and materialistic value, but other dimensions like quality and functional value have not been 
studied. Chadha \& Husband (2006) have divided the Asian economies into five stages of 'Luxe Evolution'. They have studied the brand awareness, price factor, gifting of luxury brands, status value and aesthetic value of Chinese consumers and a similar study has been done for Indian consumers. But impact of demographic variables like education on purchase of luxury brands has not been considered.

Hauck \&Stanforth (2007) have considered the impact of age on purchase of luxury brands but other demographic and psychographic variables have not been considered. Wiedmann et al. (2007) have considered financial value, functional value, personal value, social value and luxury value for luxury brands but impact of demographic and psychographic variables on purchase of luxury brands has not been considered.

Tynan et al. (2008) have considered four types of luxury value i.e. functional value, hedonic value, symbolic value and cost value. But impact of demographic variables like education on purchase of luxury brands has not been considered. In the study by Benady, David (2008), financial factors affecting purchase of luxury brands have been considered but demographic variables have not been considered.

Fionda and Moore (2009) have emphasised on a clear brand identity, premium pricing, heritage and exclusivity as a characteristic of luxury brands but other things like quality and product integrity have not been considered. Atwal \& Williams (2009) have said that luxury products no longer provide solely on functional values, but also, on emotional values and social values. But impact of demographic variables like education on purchase of luxury products has not been studied.

The study by Han, Young Jee et al. (2010) shows how purchase of luxury brands depends on wealth but other factors like age, occupation, culture, personality, education and culture have not been considered.

Jung \&Shen (2011) have studied the cultural effects on consumer behaviour but other demographic and psychographic variables have not been considered. The impact of culture on purchase of luxury brands was considered but other demographic variables were not considered in the study done by Shukla, Paurav (2011).

$\mathrm{Yu}$ et al. (2013) studied the influence of brand image, country of origin and self-congruity on internet users' purchase intention. But they have not considered the impact of demographic variables like education on purchase of luxury brands. According to Albrecht et al. (2013), it has become very important to use brand extensions for business. But other dimensions of luxury value like financial value, functional value and social value has not been considered. According to Stokburger-Sauer and Teichmann (2013), despite the fact that the functional value of luxury brands is usually not substantially higher than other non-luxury brands, luxury brands can reach substantial price premiums in the market over non-luxury ones. But they have not considered hedonic value, self-identity value and social value in their study.

Yookyung Hwang et al. (2014) have studied how a luxury consumer's desire for conspicuousness and rarity moderates the impact of price on choice of luxury brands. The gap in the study is that other dimensions of luxury value like functional value and social value have not been considered. Sandra Loureiro et al. (2014) aim to analyse how individual and social luxury values affect the customers' attitude, behavioural control and subjective norms and how these variables and past experience influence the intentions to recommend and pay more for luxury clothing in the Brazilian market. The gap in the study is that functional value of luxury brands has not been emphasized.

\section{Identification of variables}

Based on the gap analysis, following variables have been identified. The dependent variable is purchase behaviour of luxury products.

The independent variables are

(i) Different dimensions of luxury value namely (a) financial value (b) functional value (c) Individual value (d) Social value (ii) Education

\section{Theoretical construct:}

Based on the gap analysis, following variables have been identified. The dependent variable is purchase behaviour of luxury products. The independent variables are (i)Different dimensions of luxury value (ii) Education

Considering the four main luxury dimensions and gender into account, we have proposed the theoretical model shown in Fig. 1 and 2. 


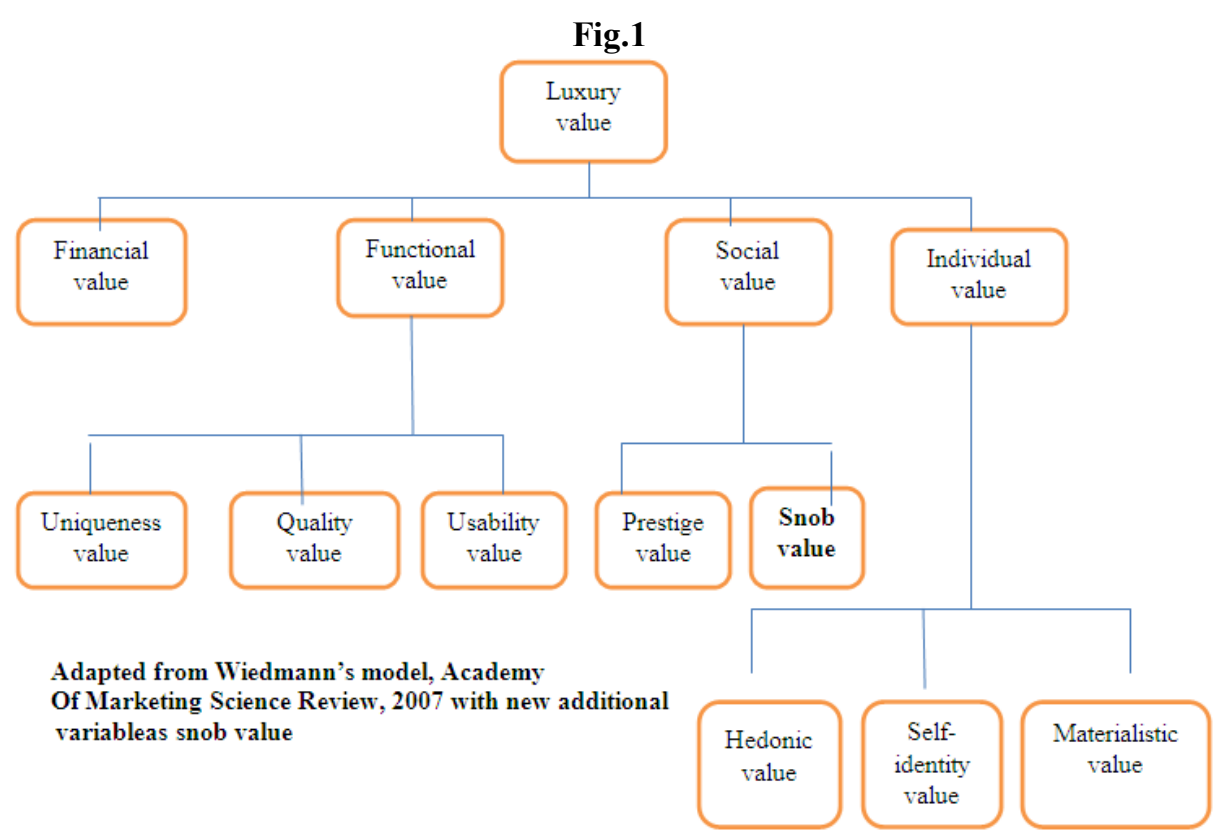

Fig.2

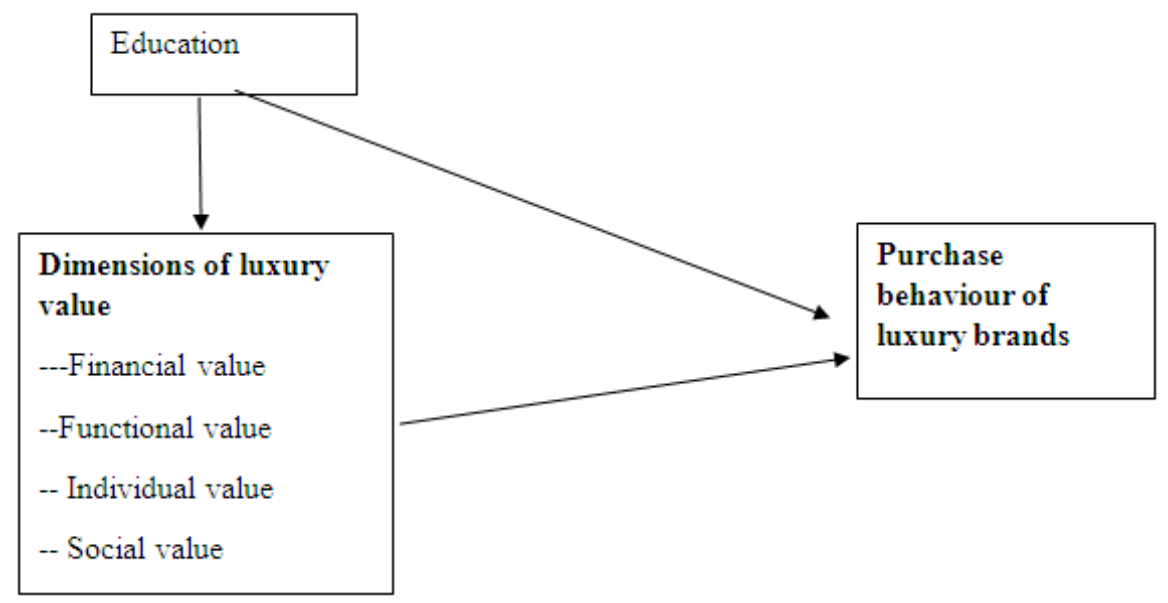

VII. Objectives of the study:

The objectives, mentioned below, will be considered:

(i) To understand the different luxury value perceptions among consumers: Here we have identified four important luxury dimensions namely financial value, functional value, social value and individual value based on our literature review.

(ii) To understand whether demographic variables like education influence the purchase behaviour of luxury brands.

(iii) A conceptual model has been made to show the influence of education on the various luxury value dimensions on purchase behaviour of luxury brands.

\section{Formulation of hypotheses:}

The hypothesis can be written as follows:

(i) First, we want to test whether there is any relation between demographic variables like education and frequency of buying luxury brands, influence to buy luxury brands and intention to purchase the same brand previously purchased.

Srinivasan et al.(2014) in their study have found that demographic variables like gender, income, age, education, religion, ethnicity, marital status and occupation can influence the purchase of luxury products. Hence the following hypothesis can be taken: 
H1: There is a relation between education and frequency of buying luxury brands

Srinivasan et al.(2014) in their study have also found that demographic variables like gender, income, age, education, religion, ethnicity, marital status and occupation are related to a consumer's influence to buy luxury brands. Hence the following hypothesis can be taken:

H2: There is a relation between education and influence to buy luxury brands

Srinivasan et al.(2014) have also found that demographic variables like gender, income, age, education, religion, ethnicity, marital status and occupation influence the intention to purchase the same brand previously purchased. Hence the following hypothesis can be taken:

H3: There is a relation between education and intention to purchase the same brand previously purchased Similarly, we want to find whether education is related to the place from where a consumer buys luxury brands and also the kind of luxury product they intend to buy.

Hence we can have the following two hypotheses:

\section{H4: There is a relation between education and the kind of luxury product a consumer intends to buy}

H5: There is a relation between education and the place from where a consumer buys luxury brands (ii) Now, we want to test whether there is any significant difference in perception of different dimensions of luxury value with respect to education.

We want to find whether financial value of the luxury brand is perceived differently by graduates, undergraduates and postgraduates. Hence we can have the hypothesis as:

H6: There is a significant difference in perception of financial value among people of different educational levels.

Similarly, we want to find whether the functional value of the luxury product is perceived differently by people of different educational levels. Hence we can have the hypothesis as:

H7: There is a significant difference in perception of functional value among people of different educational levels.

The individual value of the luxury brand can be perceived differently by people of different educational levels. Hence we can have the hypothesis as :

H8: There is a significant difference in perception of individual value among people of different educational levels.

Similarly, the social value of the luxury brand can be perceived differently by people of different educational levels. Hence we can have the hypothesis as :

H9: There is a significant difference in perception of social value among people of different educational levels.

\section{Methodology}

To measure the underlying dimensions of consumers' luxury value perceptions, in this study we have used already existing tested measures (Tianet. al., 2001; O'Cass\& McEwen, 2004; Tsai, 2005; Wiedmannet. al., 2009) and generated various items based on the literature review. The important components of luxury value dimensions are considered for constructing questionnaire items. 1200 respondents completed a questionnaire consisting of 57 items.

\section{Sample characteristics and data collection:}

The present research focuses on the purchase behaviour of consumers of luxury goods; thus, the target population is individuals from the middle class and upper middle class segment. In this case, judgement sampling and snowball sampling used to get the list of 2000 respondents and then systematic random sampling are used to select 1200 people. The Kaiser-Meyer-Olkin measure of sampling adequacy (KMO), with a value of 0.851 , which is greater than 0.7 shows that the sample size was sufficiently large to conduct factor analyses, described in the results section of this study.

The study was done during the time period from April 2013 to February 2014.

The sample of respondents is from Mumbai and consisted of both genders, age ranging from up to 25 years to more than 50 years. They were people of different educational backgrounds, occupations, income groups, marital status and religions. A sample size of 1200 people was taken. The age groups considered were 0- 
25 years, 26-30 years, 31-35 years, 36-40 years, $41-50$ years and more than 50 years. The respondents has monthly income groups as Rs. 50000-1 lakh, Rs. 1.1 lakhs -1.5 lakhs, Rs. 1.6 lakhs-2 lakhs, Rs. 2.1 lakhs- 2.5 lakhs, Rs. 2.6 lakhs-3 lakhs, Rs. 3.1 lakhs-4 lakhs, Rs. 4.1 lakhs-4.5 lakhs, Rs. 4.6 lakhs -5 lakhs, and more than Rs. 5 lakhs. This is as per the standards set by the Asian Development Bank and the 2005 Mckinsey report. Data are collected using a structured questionnaire. All respondents completed the instrument in Mumbai and Navi Mumbai. The sample seems to well represent India's middle class and upper middle class educated urban people. The sample was fairly young with $44 \%$ of respondents younger than the age of 35 and $53 \%$ between the ages of 35 and 50 years. One third identified as business people while $40 \%$ identified as professionals. The remaining $27 \%$ respondents identified as retired or homemakers or service people. The respondents covered four types of ethnicities i.e. north, south, east and west of India. Sixty two percent were single. $92 \%$ were at least college educated with $47 \%$ indicating that they had completed post-graduate work. The monthly incomes ranged from Rs. 50000 to more than Rs. 5 lakhs. This is as per the standards set by the Asian Development Bank and the 2005 Mckinsey report.

\section{Quantitative Data Analysis}

The quantitative data analysis techniques used in this study are (1) Chi-square test (2) Factor analysis (3) Kruskal-Wallis H test

To understand the different luxury value perceptions among consumers, factor analysis was first performed on the questionnaire. This will give us the important luxury value dimensions which influence the purchase behaviour of luxury brands. Chi square test is used to see whether education is related to purchase behaviour of luxury brands. Also, Kruskal-Wallis H test is used to see how each dimension of luxury value is influenced by education.

\section{Results}

The study was intended to find how education influences the important luxury dimensions and also the purchase behaviour of luxury brands. It involved the following steps:

(a) According to the factor analysis results, a nine- factor solution whichexplains $56.2 \%$ of total variance in 42 items wasobtained. All itemsgrouped meaningfully into the factors with highloadings. Factors with Eigen values more than 1 were considered. The nine factors were named as prestige value, self-identity value, quality value, uniqueness value, hedonic value, materialistic value, snob value, usability value and financial value.

(b) Reliability of the scalesis measured by computing the Cronbach alpha. For allthe nine factors used in this research, reliabilityvalues had a range between 0.7 and 0.83 .

Testing of hypotheses summary results are given below.

\section{Summary of testing of hypotheses}

\begin{tabular}{|c|c|c|c|c|}
\hline Hypothesis & Test used & Significance value & $\begin{array}{l}\text { Status of } \\
\text { hypothesis }\end{array}$ & Comment \\
\hline $\begin{array}{l}\text { 1. There is a relation } \\
\text { between education and } \\
\text { frequency of buying } \\
\text { luxury brands }\end{array}$ & Chi square test & 0.093 & Rejected & $\begin{array}{l}\text { There is no relation } \\
\text { between education and } \\
\text { frequency of buying } \\
\text { luxury brands. }\end{array}$ \\
\hline $\begin{array}{l}\text { 2. There is a relation } \\
\text { between education and } \\
\text { influence to buy luxury } \\
\text { brands }\end{array}$ & Chi square test & 0.365 & Rejected & $\begin{array}{l}\text { There is no relation } \\
\text { between education and } \\
\text { influence to buy luxury } \\
\text { brands }\end{array}$ \\
\hline $\begin{array}{l}\text { 3. There is a relation } \\
\text { between education and } \\
\text { intention to purchase } \\
\text { the same brand } \\
\text { previously purchased }\end{array}$ & Chi-square test & 0.852 & Rejected & $\begin{array}{l}\text { There is no relation } \\
\text { between education and } \\
\text { intention to purchase } \\
\text { the same brand } \\
\text { previously purchased }\end{array}$ \\
\hline $\begin{array}{l}\text { 4.There is a relation } \\
\text { between education and } \\
\text { the kind of luxury } \\
\text { product a consumer } \\
\text { intends to buy }\end{array}$ & Chi-square test & 0.12 & Rejected & $\begin{array}{l}\text { There is no relation } \\
\text { between educaton and } \\
\text { the kind of luxury } \\
\text { product a consumer } \\
\text { intends to buy }\end{array}$ \\
\hline $\begin{array}{l}5 . \text { There is a relation } \\
\text { between education and } \\
\text { the place from where a } \\
\text { consumer buys luxury } \\
\text { brands }\end{array}$ & Chi-square test & 0.000 & Accepted & $\begin{array}{l}\text { There is a relation } \\
\text { between education and } \\
\text { the place from where a } \\
\text { consumer buys }\end{array}$ \\
\hline 6.There is a significant & Kruskal-Wallis H & 0.000 & Accepted & There is a significant \\
\hline
\end{tabular}




\begin{tabular}{|c|c|c|c|c|}
\hline $\begin{array}{l}\text { difference in perception } \\
\text { of financial value } \\
\text { among people of } \\
\text { different educational } \\
\text { levels. }\end{array}$ & test & & & $\begin{array}{l}\text { difference in perception } \\
\text { of financial value } \\
\text { among people of } \\
\text { different educational } \\
\text { levels }\end{array}$ \\
\hline $\begin{array}{l}7(\text { a) There is a } \\
\text { significant difference in } \\
\text { perception of quality } \\
\text { value among people of } \\
\text { different educational } \\
\text { levels. }\end{array}$ & $\begin{array}{l}\text { Kruskal-Wallis H } \\
\text { test }\end{array}$ & 0.149 & Rejected & $\begin{array}{l}\text { There is no significant } \\
\text { difference in perception } \\
\text { of quality value among } \\
\text { people of different } \\
\text { educational levels. }\end{array}$ \\
\hline $\begin{array}{l}\text { 7(b) There is a } \\
\text { significant difference in } \\
\text { perception of } \\
\text { uniqueness value } \\
\text { among people of } \\
\text { different educational } \\
\text { levels. }\end{array}$ & $\begin{array}{l}\text { Kruskal-Wallis H } \\
\text { test }\end{array}$ & 0.535 & Rejected & $\begin{array}{l}\text { There is no significant } \\
\text { difference in perception } \\
\text { of uniqueness value } \\
\text { among people of } \\
\text { different educational } \\
\text { levels. }\end{array}$ \\
\hline $\begin{array}{l}7(c) \text { There is a } \\
\text { significant difference in } \\
\text { perception of usability } \\
\text { value among people of } \\
\text { different educational } \\
\text { levels. }\end{array}$ & $\begin{array}{l}\text { Kruskal-Wallis H } \\
\text { test }\end{array}$ & 0.462 & Rejected & $\begin{array}{l}\text { There is no significant } \\
\text { difference in perception } \\
\text { of usability value } \\
\text { among people of } \\
\text { different educational } \\
\text { levels. }\end{array}$ \\
\hline $\begin{array}{l}\text { 8(a) There is a } \\
\text { significant difference in } \\
\text { perception of } \\
\text { materialistic value } \\
\text { among people of } \\
\text { different educational } \\
\text { levels. }\end{array}$ & $\begin{array}{l}\text { Kruskal-Wallis H } \\
\text { test }\end{array}$ & 0.366 & Rejected & $\begin{array}{l}\text { There is no significant } \\
\text { difference in perception } \\
\text { of materialistic value } \\
\text { among people of } \\
\text { different educational } \\
\text { levels. }\end{array}$ \\
\hline $\begin{array}{l}8(b) \text { There is a } \\
\text { significant difference in } \\
\text { perception of hedonic } \\
\text { value among people of } \\
\text { different educational } \\
\text { levels. }\end{array}$ & $\begin{array}{l}\text { Kruskal-Wallis H } \\
\text { test }\end{array}$ & 0.339 & Rejected & $\begin{array}{l}\text { There is no significant } \\
\text { difference in perception } \\
\text { of hedonic value among } \\
\text { people of different } \\
\text { educational levels. }\end{array}$ \\
\hline $\begin{array}{l}8(\text { c) There is a } \\
\text { significant difference in } \\
\text { perception of self- } \\
\text { identity value among } \\
\text { people of different } \\
\text { educational levels. }\end{array}$ & $\begin{array}{l}\text { Kruskal-Wallis H } \\
\text { test }\end{array}$ & 0.036 & Accepted & $\begin{array}{l}\text { There is a significant } \\
\text { difference in perception } \\
\text { of self-identity value } \\
\text { among people of } \\
\text { different educational } \\
\text { levels. }\end{array}$ \\
\hline $\begin{array}{l}9(\text { a) } \text { There is a } \\
\text { significant difference in } \\
\text { perception of prestige } \\
\text { value among people of } \\
\text { different educational } \\
\text { levels. }\end{array}$ & $\begin{array}{l}\text { Kruskal-Wallis H } \\
\text { test }\end{array}$ & 0.371 & Rejected & $\begin{array}{l}\text { There is no significant } \\
\text { difference in perception } \\
\text { of prestige value among } \\
\text { people of different } \\
\text { educational levels. }\end{array}$ \\
\hline $\begin{array}{l}\text { 9(b) There is a } \\
\text { significant difference in } \\
\text { perception of snob } \\
\text { value among people of } \\
\text { different educational } \\
\text { levels. }\end{array}$ & $\begin{array}{l}\text { Kruskal-Wallis H } \\
\text { test }\end{array}$ & 0.156 & Rejected & $\begin{array}{l}\text { There is no significant } \\
\text { difference in perception } \\
\text { of snob value among } \\
\text { people of different } \\
\text { educational levels. }\end{array}$ \\
\hline
\end{tabular}

\section{Findings}

(a) From Chi square test: When the influence of education on purchase of luxury products was considered, chi square test was used and the following results were obtained:

(i) There is no relation between education and frequency of buying luxury products.

(ii) There is no relation between education and kind of luxury product that consumers intend to buy.

(iii) There is a relation between education and the place from which they buy luxury brands. Malls are preferred more by graduates, postgraduates and doctorates while undergraduates may buy luxury brands either from speciality stores or malls or company outlets.

(iv) There is no relation between education and influence to buy luxury products.

(v) There is no relation between education and intention to repurchase the brand.

\section{(b) From Kruskal-Wallis $\mathrm{H}$ test:}

Kruskal-Wallis $\mathrm{H}$ test was used to find whether there is any significant difference in the perception of the different dimensions of luxury value with respect to education. The following results were obtained: 
(i) There is a significant difference in perception of financial value among people of different educational levels. Graduates and postgraduates showed a higher rating towards financial value as compared to undergraduates.

(ii) There is no significant difference in perception of quality value among people of different educational levels.

(iii) There is no significant difference in perception of uniqueness value among people of different educational levels.

(iv)There is no significant difference in perception of usability value among people of different educational levels.

(v) There is no significant difference in perception of materialistic value among people of different educational levels.

(vi) There is no significant difference in perception of hedonic value among people of different educational levels.

(vii) There is asignificant difference in perception of self-identity value among people of different educational levels. Graduates, postgraduates and doctorates showed a higher rating towards self-identity value as compared to undergraduates.

(viii) There is no significant difference in perception of prestige value among people of different educational levels.

(ix) There is no significant difference in perception of snob value among people of different educational levels.

\section{Conclusions}

Using the chi-square test,it is found that there is a relation between education and the place from which they buy luxury brands. Malls are preferred more by graduates, postgraduates and doctorates while undergraduates may buy luxury brands either from speciality stores or malls or company outlets. Using the Kruskal-Wallis $\mathrm{H}$ test, there is a significant difference in perception of financial value among people of different educational levels. Graduates and postgraduates showed a higher rating towards financial value as compared to undergraduates. There is a significant difference in perception of self-identity value among people of different educational levels. Graduates, postgraduates and doctorates showed a higher rating towards self-identity value as compared to undergraduates.

\section{Managerial implications}

The results of this research have practical implications for marketers working in the luxury industry. The results suggest that a focus on designing and managing optimal products together with exclusivity can create positive emotions. To effectively react to the needs, wants and values of purchasers is vital, especially in an increasingly competitive global marketplace. Positioning and segmentation decisions have to be made on a global level. From a market positioning perspective, monitoring the evaluative criteria of consumers can help marketers to recognise and focus on the specific luxury dimensions, with special reference to education. Luxury brand companies can understand people of different educational levels respond to the different luxury value dimensions and how the luxury products can cater to the requirements of each group.

\section{Limitations and scope for further research}

Firstly, a particular limitation of this study was that the respondents were all from Mumbai and Navi Mumbai and represented only one specific demographic group i.e. urban people of India. Thus, the results might vary if this study was repeated in different cities or regions of India. In terms of further research, therefore, researchers should consider expanding the study focus to different areas and different populations.

Secondly, we have considered the influence of education on the different luxury value dimensions and the purchase behaviour of luxury products. Other demographic variables like age, occupation, income group, gender, ethnicity and marital status can be considered to study their influence on purchase behaviour of luxury brands.

Thirdly, only the overall perceptions about luxury value have been tested. We can apply similar analysis for a specified luxury product or service.

\section{References:}

[1]. Abdolvand, M.A., Reihani, N (2013), 'The effect of brand association in psycho-social and psycho-personality antecedents: a conceptual model of conspicuous consumption among youth adults', Research Journal of Applied Sciences, Engineering and Technology, 6(6): 1012-1022

[2]. Achabou, M.A., \&Dekhili, S. (2013), 'Luxury and sustainable development: Is there a match?', Journal of Business Research, 66(10) : 1896-1903

[3]. Chadha, R., \& Husband, P. (2006), The cult of the luxury brand: Inside Asia's love affair with luxury. London: Nicholas Brealey International.

[4]. Chaudhuri, H. R., \&Majumdar, S. (2006), 'Of diamonds and desires: understanding conspicuous consumption from a contemporary marketing perspective, Academy of Marketing Science Review, 6 (11) : 256-267.

[5]. Ching-Yaw Chen, Chia-Hui Chao, Yu-Je Lee and Tsai Pei-chuan (2011), 'Exploration of the differences in Taiwanese women's 
purchasing decisions towards luxury goods and general products'.

[6]. Danziger, P. (2004), 'Meet the young affluents: How the "Want-It-All, Want-It-Now" generation is changing the luxury market and what brands need to do about ' to it.' http://www.whypeoplebuy.com/cms/Home Page/Speeches Presentations.php

[7]. Dubois, B. \&Paternault, C. (1995), "Observations: Understanding the World of International Luxury Brands: The Dream Formula", Journal of Advertising Research, 35(4): 69-76

[8]. Fionda, A. M., \& Moore, C. M. (2008), 'The anatomy of the luxury fashion brand', Journal of Brand Management, 16 (5/6) : 347 363.

[9]. Fiske, N., and Silverstien, M. (2002), “Trading Up: The new Luxury and Why we Need It”, Boston Consulting Group.

[10]. Heine, K. (2011), "The concept of luxury brands". Luxury Brand Management, No.1 TechnischeUniversität Berlin.

[11]. Kapferer, J.N. (1996), "Managing Luxury Brands", Journal of Brand Management, pp. 251-260

[12]. MiremadiAlireza, FotoohiHiva, SadehFarhad, TabriziFarhad, JavidigholipourmashhadKasra (2011), 'The Possible Effects of Need for Uniqueness's Dimensions on Luxury Brands: Case of Iran and UAE', International Journal of Marketing Studies, 3 (3)

[13]. Sonny Nwankwo, Nicolas Hamelin, Meryem Khaled (2014), Consumer values, motivation and purchase intention for luxury goods', Journal of Retailing and Consumer Services

[14]. SrichanSriviroj (2007), 'Purchasing Luxury Goods: consumer behaviour of international students in the UK', Masters dissertation in International Business

[15]. Srinivasan, R, Srivastava, R.K.\& Bhanot, S (2013), 'Study of the influence of demographic variables on purchase behaviour of luxury brands', International Journal of Contemporary Management Studies, 1(1): 181-195

[16]. Srinivasan, R, Srivastava, R.K.\& Bhanot, S (2014), 'Identifying luxury value dimensions for consumers and using these dimensions for market segmentation', Sydenham Management Review, 3(2) : 83-90

[17]. Wiedmann, K., Hennigs, N., \&Siebels, A. (2007), 'Measuring consumers' luxury value perception: A cross cultural framework', Academy of Marketing Science Review, 7 (7): 333-361.

\title{
Web References
}

\author{
[18]. en.wikipedia.org/wiki/Luxury goods \\ [19]. www.pauravshukla.com/segmenting-luxury-brand-consumers \\ [20]. www.luxurydaily.com/tag/emerging-markets/ \\ [21]. www.luxurydaily.com \\ [22]. blog.sina.com.cn/s/blog 53cbff2e0100krcd.html, as seen on Nov.2013). \\ [23]. www.mslgroup.com
}

Table 1: education * awareofluxurybrands Chi-Square Tests

\begin{tabular}{|c|c|c|c|}
\hline & Value & df & Asymp. Sig. (2-sided) \\
\hline Pearson Chi-Square & $15.244^{2}$ & 3 & .002 \\
\hline Likelihood Ratio & 13.606 & 3 & .003 \\
\hline Linear-by-Linear Association & 4.112 & 1 & .043 \\
\hline $\mathrm{N}$ of Valid Cases & 1200 & & \\
\hline
\end{tabular}

Table 2: education * buyluxurybrands Chi-Square Tests

\begin{tabular}{|l|r|r|r|}
\hline & Value & df & Asymp. Sig. (2-sided) \\
\hline Pearson Chi-Square & $16.166^{6}$ & 3 & .001 \\
Likelihood Ratio & 16.216 & 3 & .001 \\
Linear-by-Linear Association & 7.380 & 1 & .007 \\
N of Valid Cases & 1200 & & \\
\hline
\end{tabular}

Table 3: education * howoftenbuyluxuryproducts Chi-Square Tests

\begin{tabular}{|l|r|r|r|}
\hline & \multicolumn{1}{|c|}{ Value } & df & Asymp. Sig. (2-sided) \\
\hline Pearson Chi-Square & $18.828^{2}$ & 12 & .093 \\
Likelihood Ratio & 17.758 & 12 & .123 \\
Linear-by-Linear Association & .234 & 1 & .628 \\
N of Valid Cases & 1200 & & \\
\hline
\end{tabular}

Table 4:education * kindofluxuryproductyouintendtobuy Chi-Square Tests

\begin{tabular}{|l|r|r|r|}
\hline & Value & df & Asymp. Sig. (2-sided) \\
\hline Pearson Chi-Square & $25.191^{2}$ & 18 & .120 \\
Likelihood Ratio & 24.040 & 18 & .154 \\
Linear-by-Linear Association & .937 & 1 & .333 \\
N of Valid Cases & 1200 & & \\
\hline
\end{tabular}


Table 5: education * fromwhereyoubuyluxurybrands Chi-Square Tests

\begin{tabular}{|l|r|r|r|}
\hline & Value & df & Asymp. Sig. (2-sided) \\
\hline Pearson Chi-Square & 61.608 & 12 & .000 \\
Likelihood Ratio & 59.483 & 12 & .000 \\
Linear-by-Linear Association & 26.798 & 1 & .000 \\
N of Valid Cases & 1200 & & \\
\hline
\end{tabular}

Table 6: education * influencetobuyluxuryproducts

\begin{tabular}{|l|r|r|r|}
\hline \multicolumn{1}{|c|}{ Chi-Square Tests } \\
\hline Pearson Chi-Square & Value & df & Asymp. Sig. (2-sided) \\
Likelihood Ratio & 16.262 & 15 & .365 \\
Linear-by-Linear Association & 16.904 & 15 & .325 \\
N of Valid Cases & 2.219 & 1 & .136 \\
\hline
\end{tabular}

Table 7: education * intentiontorepurchasebrand Chi-Square Tests

\begin{tabular}{|c|c|c|c|}
\hline & Value & $\mathrm{df}$ & Asymp. Sig. (2-sided) \\
\hline $\begin{array}{l}\text { Pearson Chi-Square } \\
\text { Likelihood Ratio } \\
\text { Linear-by-Linear Association } \\
\text { N of Valid Cases }\end{array}$ & $\begin{array}{r}2.647^{\mathrm{a}} \\
2.660 \\
.028 \\
1200\end{array}$ & $\begin{array}{l}6 \\
6 \\
1\end{array}$ & $\begin{array}{r}.852 \\
.850 \\
.866\end{array}$ \\
\hline
\end{tabular}

Tables 8-15

Hypothesis Test Summary

\begin{tabular}{|c|c|c|c|c|}
\hline & Null Hypothesis & Test & Sig. & Decision \\
\hline 1 & $\begin{array}{l}\text { The distribution of bestquality is the } \\
\text { same across categories of } \\
\text { education. }\end{array}$ & $\begin{array}{l}\text { Independent- } \\
\text { Samples } \\
\text { Kruskal- } \\
\text { Uíallis Test }\end{array}$ & .149 & $\begin{array}{l}\text { Retain the } \\
\text { null } \\
\text { hypothesis. }\end{array}$ \\
\hline
\end{tabular}

Asymptotic significances are displayed. The significance level is 05 .

Hypothesis Test Summary

\begin{tabular}{|c|c|c|c|c|}
\hline & Null Hypothesis & Test & Sig. & Decision \\
\hline 1 & $\begin{array}{l}\text { The distribution of } \\
\text { willingtopaypremiumprice } \\
\text { same across oategories of } \\
\text { education. }\end{array}$ & $\begin{array}{l}\text { Independent- } \\
\text { is th } 6 \text { amples } \\
\text { Kruskal- } \\
\text { villis Test }\end{array}$ & .000 & $\begin{array}{l}\text { Reject the } \\
\text { nuil } \\
\text { hypothesis. }\end{array}$ \\
\hline
\end{tabular}

Asymptotic significances are displayed. The significance level is .05.

Hypothesis Test Summary

\begin{tabular}{|c|c|c|c|c|}
\hline & Null Hypothesis & Test & Sig. & Decision \\
\hline 1 & $\begin{array}{l}\text { The distribution of uniqueness is th } \\
\text { same across categories of } \\
\text { education. }\end{array}$ & $\begin{array}{l}\text { Lndependent- } \\
\text { Samples } \\
\text { Kruskal- } \\
\text { vilalis Test }\end{array}$ & .535 & $\begin{array}{l}\text { Retain the } \\
\text { null } \\
\text { hypothesis. }\end{array}$ \\
\hline
\end{tabular}

Asymptotic significances are displayed. The significance level is .05 . 
Hypothesis Test Summary

\begin{tabular}{|c|c|c|c|c|}
\hline & Null Hypothesis & Test & Sig. & Decision \\
\hline 1 & $\begin{array}{l}\text { The distribution of } \\
\text { expressmyindividuality is the same } \\
\text { across categories of education. }\end{array}$ & $\begin{array}{l}\text { Independent- } \\
\text { Samples } \\
\text { Sarusal- } \\
\text { Volilis Test }\end{array}$ & .036 & $\begin{array}{l}\text { Reject the } \\
\text { null } \\
\text { hypothesis. }\end{array}$ \\
\hline
\end{tabular}

Asymptotic significances are displayed. The significance level is .05 .

\section{Hypothesis Test Summary}

\begin{tabular}{|c|c|c|c|c|}
\hline & Null Hypothesis & Test & Sig. & Decision \\
\hline 1 & $\begin{array}{l}\text { The distribution of } \\
\text { ibegintostopusinguvellknomnproduc } \\
\text { s is the same across categories of } \\
\text { education. }\end{array}$ & $\begin{array}{l}\text { Independent- } \\
\text { cSamples } \\
\text { Kruskal- } \\
\text { Noillis Test }\end{array}$ & .156 & $\begin{array}{l}\text { Retain the } \\
\text { null } \\
\text { hypothesis. }\end{array}$ \\
\hline
\end{tabular}

Asymptotic significances are displayed. The significance level is 05 .

Hypothesis Test Summary

\begin{tabular}{|c|c|c|c|c|}
\hline & Null Hypothesis & Test & Sig. & Decision \\
\hline 1 & $\begin{array}{l}\text { The distribution of } \\
\text { iregardluxurybrandsasgiftsibuyfortre } \\
\text { atingmyself is the same across } \\
\text { categories of education. }\end{array}$ & $\begin{array}{l}\text { Independent- } \\
\text { eSamples } \\
\text { Kruskal- } \\
\text { volilis Test }\end{array}$ & .339 & $\begin{array}{l}\text { Retain the } \\
\text { null } \\
\text { hypothesis. }\end{array}$ \\
\hline
\end{tabular}

Asymptotic significances are displayed. The significance level is 05 .

Hypothesis Test Summary

\begin{tabular}{|c|c|c|c|c|}
\hline & Null Hypothesis & Test & Sig. & Deoision \\
\hline 1 & $\begin{array}{l}\text { The distribution of } \\
\text { selfsactualisationisanimportantmot } \\
\text { ator is the same across oategories } \\
\text { of education. }\end{array}$ & $\begin{array}{l}\text { Independent- } \\
\text { tisamples } \\
\text { Kruskal- } \\
\text { viallis Test }\end{array}$ & 366 & $\begin{array}{l}\text { Retain the } \\
\text { null } \\
\text { hypothesis. }\end{array}$ \\
\hline
\end{tabular}

Asymptotic significances are displayed. The significance level is 05 .

Hypothesis Test Summary

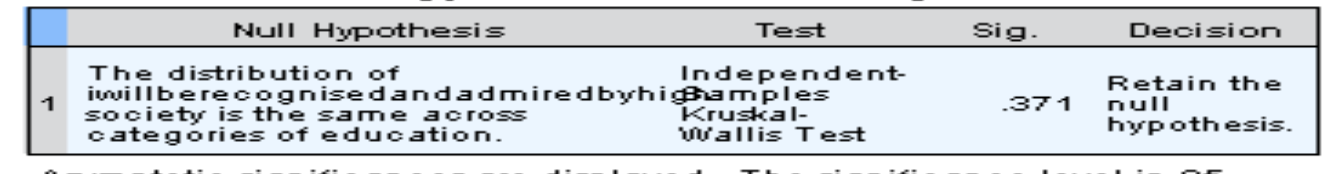

Asymptotic significances are displayed. The significance level is .05. 